Volume 13

Issue 2 Rethinking Genocide, Mass Atrocities,

and Political Violence in Africa: New Directions,

Article 11

New Inquiries, and Global Perspectives

6-2019

\title{
Buying Peace or Building Peace: Rethinking Non-Coercive Approach to the Management of Non-State Armed Groups involved in Mass Atrocity
}

Owonikoko B. Saheed

Modibbo Adama University of Technology

Nathaniel D. Danjibo

University of Ibadan

Follow this and additional works at: https://digitalcommons.usf.edu/gsp

\section{Recommended Citation}

Saheed, Owonikoko B. and Danjibo, Nathaniel D. (2019) "Buying Peace or Building Peace: Rethinking NonCoercive Approach to the Management of Non-State Armed Groups involved in Mass Atrocity," Genocide Studies and Prevention: An International Journal: Vol. 13: Iss. 2: 116-128.

DOI:

https://doi.org/10.5038/1911-9933.13.2.1701

Available at: https://digitalcommons.usf.edu/gsp/vol13/iss2/11

This Articles is brought to you for free and open access by the Open Access Journals at Digital Commons @ University of South Florida. It has been accepted for inclusion in Genocide Studies and Prevention: An International Journal by an authorized editor of Digital Commons @ University of South Florida. For more information, please contact digitalcommons@usf.edu. 


\title{
Buying Peace or Building Peace: Rethinking Non-Coercive Approach to the Management of Non-State Armed Groups involved in Mass Atrocity
}

\author{
Owonikoko Babajide Saheed \\ Modibbo Adama University of Technology \\ Yola, Adamawa State, Nigeria \\ Nathaniel D. Danjibo \\ University of Ibadan \\ Ibadan, Oyo State, Nigeria
}

The commission of mass atrocities by non-state armed groups (NSAGs) is becoming increasingly rife in contemporary armed conflicts. As the agent with a monopoly on the legitimate use of force, the state has a responsibility to engage NSAGs for peace and security. Although, there is an intensive academic debate on how best to engage NSAGs; either to use a coercive approach, a non-coercive approach or a combination of both, contemporary reality suggests states often opt for a non-coercive approach. This paper interrogates the utility of a non-coercive approach in the engagement of NSAGs by using the amnesty programs implemented in the Niger Delta and North East regions of Nigeria. This paper holds that it is not just enough to adopt a monodimensional non-coercive approach in engaging NSAGs. Any non-coercive approach that seeks to foster sustainable peace must promote society-wide reconciliation and address the root causes of the grievances that morphed into hostility and armed conflict.

\section{Introduction}

Since the end of the Cold War, there has been a significant change in the security architecture of the modern state. Armed conflicts are no longer triggered by external threats; rather they are the result of tensions, animosities, and confrontations between or among actors and forces from within the territories of countries. Therefore, the security challenges facing modern states have changed from the prevention of external aggression to the management of internal security crises, which often emerge in different forms, including sectarian violence, ethnic conflict, resourcebased conflict, communal clashes, and other forms of militancy and insurrection against the state. The emergence of this "new conflict" is typically referred to in extant literature as internal or intra-state conflict. ${ }^{1}$ It has also been given several other descriptors by scholars. These include: low intensity armed conflict, ${ }^{2}$ small wars, ${ }^{3}$ uncivil war, ${ }^{4}$ new war, ${ }^{5}$ Hobbesian war, ${ }^{6}$ war of the third

${ }^{1}$ Jeronimo Delgado Caicedon, "Paramilitary Groups and National Security: A Comparison Between Cambodia and Sudan," African Centre for the Constructive Resolution of Conflict, Conflict trends 4 (2009), 3-12.

${ }^{2}$ Grant T. Hammond, "Low Intensity Conflict: War by another name," Journal of Small Wars and Insurgencies 1, no. 3 (1990), 226-238; Max G. Manwaring, ed., Uncomfortable War: Toward A New Paradigm of Low Intensity Conflict (Boulder: Westview Press, 1991); David J. Dean, ed., Low Intensity Conflict and Technology (Alabama: Air University Press, 1986); Graham H. Turbiville, Jr, "Preface: Future Trend in Low Intensity Conflict," Low Intensity Conflict and Law Enforcement 11, no. 2-3 (2002), 155-163. DOI: 10.1080/0966284042000279957; Stephen Blank, et al., Low-Intensity Conflict in The Third World (Alabama: Air University Press, 1988); Avi Kober, "Low-intensity Conflicts: Why the Gap between Theory and Practice?," Defense and Security Analysis 18, no. 1 (2002), 15-38; Michael L. R. Smith, "Guerrillas in the Mist: Reassessing Strategy and Low Intensity Warfare," Review of International Studies 18, no. 1 (January 2003), 19-37. DOI: 10.1017/ S0260210503000020; Stuart Kinross, "Clausewitz and Low intensity Conflict," Journal of Strategic Studies 27, no. 1 (2003).

${ }^{3}$ Tarak Barkawi, “On the Pedagogy of 'small wars,"' International Affair 80, no.1 (January 2004), 19-37. DOI: 10.1111/j.14682346.2004.00363.x; Charles E. Callwell, Small Wars: Their Principles and Practice, 3rd ed. (Lincoln: University of Nebraska Press, 1994); William J. Olson, "Preface: Small Wars Considered," Annals of American Academy of Political and Social Science 541, no. 1 (September 1995), 8-19.

${ }^{4}$ Donald M. Snow, Uncivil War: International Security and the New Internal Conflicts (Boulder: Lynne Rienner Publishers, 1996).

${ }^{5}$ Mary Kaldor, New and Old Wars: Organized Violence in Global Era (Oxford: Polity Press, 1999).

${ }^{6}$ Martin Van Creveld, The Transformation of Wars (New York: The Free Press, 1991). 
kind, ${ }^{7}$ irregular war, ${ }^{8}$ and fourth generation armed conflict $^{9}$ among others. These usually pit the state against organized armed groups. Armed groups play significant roles in the perpetration and sustenance of this kind of conflict and one of the consequences of this new form of conflict is there is a significant increase in mass atrocities targeted - directly or indirectly - at civilian populations. Ramsbotham and Woodhouse cited in Harris and Kelly note these horrendous manifestations when they observed that during the First World War, only five percent of casualties were among the civilian population, while in the Second World War, the number of casualties from among civilian populations was fifty percent. ${ }^{10}$ Since the 1990s however, they observed the number of civilian population casualties has increased to an astonishing eighty percent. Although, these scholars were referring to the late 1990s, the situation has not changed. Globally, civilians continue to be the main casualties in situations of armed conflict.

There are at least two reasons for increased civilian casualties in contemporary armed conflict contexts. First, the nature of contemporary armed conflict. Contemporary warfare is internal, involves elements from within the state against the state, and often lacks a designated battlefield. This makes communities the new battlefield. Furthermore, armed groups are not easily identifiable. Moreover, because of the asymmetrical nature of their power compared to the state, armed groups engage in hit-and-run tactics. They target state security forces and become mixed up with civilians. In the process, civilians are caught in the crossfire. In 2010, Congolese civilians in the millions were killed in the crossfire of the civil war between the national army and the various rebel groups in the state. ${ }^{11}$ This gives credence to the popular African adage among the Yoruba of Southwestern Nigeria, which states when two elephants fight, it is the grasses that suffer.

Second, civilians are increasingly targeted in contemporary armed conflict situations by nonstate armed groups. Armed groups, however, are not the only element involved in mass violence against civilian populations in armed conflict. Civilians can, and are, targeted deliberately and strategically by states either through the state's security forces or deliberate policies. For instance, during the Nigerian Civil War, the Nigerian military government led by General Yakubu Gowon strategically imposed a policy of starvation on Biafran civilians in order to force the Biafran army into submission. ${ }^{12}$ Furthermore, the Assad regime in Syria has been repeatedly identified as having used chemical weapons on its own civilians in the on-going civil war. On the other hand, a state may sponsor non-state armed groups to do its bidding, including killing civilians considered a threat to the state. The oft-cited example of the Sudanese government's use of the Janjaweed militia to fight the Justice and Equality Movement is a key example. In the process, this led to the Darfur genocide where between 200,000 and 400,000 black African civilians were murdered and millions displaced in the space of three years. ${ }^{13}$

However, the mass violence perpetrated by armed groups can often be more barbaric and horrendous in magnitude and severity. The armed conflict in Sierra Leone is one such example of the atrocities perpetrated by some non-state armed groups on civilians. The atrocities and mass violence directed at civilians over the course of the conflict were used as both a military

\footnotetext{
${ }^{7}$ Kalevi J. Holsti, The State, War and the State of War (Cambridge, UK: Cambridge University Press, 1996).

${ }^{8}$ Stathis N. Kalyvas and Matthew Adam Kocher, "Ethnic Cleavages and Irregular War: Iraq and Vietnam," Politics and Society, no. 2 (June 2007), 35. DOI: 10.1177/0032329207302403

${ }^{9}$ Williams S. Lind, Keith Nightengale, John F. Schmitt, Joseph W. Sutton and Gary I. Wilson, “The Changing Face of War into the Fourth Generation," Marine Corp Gazette 85, no. 11 (October 1989), accessed November 25, 2018, https://www. mca-marines.org/gazette/2001/11/changing-face-war-fourth-generation.

${ }^{10}$ Peter Harris and Ben Reilly, eds., Democracy and Deep-Rooted Conflict: Options for Negotiators (Stockholm: International Institute for Democracy and Electoral Assistance, 1998), accessed November 25, 2018, http://eprpinformation.org/files/ peaceprocesses/negotiations/ddrc_options-for-negociators-1of4.pdf.

${ }^{11}$ Robert I. Rotberg, "Deterring Mass Atrocity Crimes: The Cause of Our Era," in Mass Atrocity Crimes: Preventing Future Outrages, ed. Robert I. Rotberg. (Washington DC: Brookings Institute Press, 2010).

${ }^{12}$ For a detailed discussion of this recent literature see Chinua Achebe, There was a Country: A Personal History of Biafra (London: Penguin Books, 2012).

${ }^{13}$ Glenn Kessler and Colum Lynch, “U.S. Calls Killings in Sudan Genocide: Khartoum and Arab Militias are Responsible," Washington Post, September 10, 2004, accessed October 28, 2018, http://www.washington.com/wp-dyn/article/A83642004sep9.html.
} 
and political weapon/strategy. Those amputated, gang-raped, mutilated, and abducted were deliberately targeted to send a message to the Sierra Leonean government under Pa Tejan Kabbah. During her field trip to Sierra Leone, Martha Foy narrated the story of a 50 year old widow who was raped by a teenage rebel called commander "Don't blame God" and subsequently had her two legs amputated.

I pleaded but commander "Don't blame God" said he was going to kill me if I don't lie down. I told him it had been such a long time since I had sex. During the rape, I was pleading with him saying, "Don't kill me, please don't kill me." He was so rough with me. Then he took me up a big dune above Mattru village. As we were walking, he said he was going to kill me. I pleaded with him and he said he was going to kill me, and then again said, "I have changed my mind, I'm going to give you a letter." When we got there I saw many more women, and I was stripped naked down to my underwear. It was humiliating, then they asked me to sit down and wait. Commander "Don't Blame God" said, "I have a letter for you but wait for the cutlass man to come." Then the one with the matchet came and told me to put out my left leg. It took them three chops with the cutlass to cut off my leg. After this, I beg them not to cut my other leg but they struggled with me and a rebel held it down and cut it off.... ${ }^{14}$

The quote above is a typical example of the mass atrocity crimes deliberated directed at civilians by armed groups in armed conflict situations. Reason for this magnitude of atrocity committed by armed non-state groups is that most members of armed groups are youths and children who are not bounded by international conventions on armed conflict and war. Furthermore, unlike states that are easily recognized in the international arena and can be sanctioned by the international community when unregulated violence is used and, particularly against civilians, members of NSAGs are usually faceless and unrecognized in the international arena. ${ }^{15}$

The previous explanation highlights a strong link between armed conflict and violence and the commission of mass atrocities. ${ }^{16}$ In his study on the link between mass atrocities and armed conflicts, Alex Bellamy lends credence to this point by bringing the linkage to the fore more succinctly with statistical figures to show that armed conflict contexts provide a suitable environment for mass atrocities. Accordingly, Bellamy highlights that out of 103 episodes of mass killing defined as involving a minimum of 5000 civilians intentionally killed between 1945 and 2010, sixty-nine cases - totaling sixty-seven percent -occurred within the context of armed conflict, and thirty-four cases - totaling thirty-three percent -occurred in "peacetime." Bellamy further notes that four of the "peacetime mass atrocity cases out of the 34 occurred as post-war retribution in countries that had recently experience armed conflict in which mass atrocities were committed."17 The conclusion that can be drawn from establishing a link between atrocities and armed conflict is that efforts made to prevent, reduce, or address mass atrocity crimes must start with preventing, reducing, or addressing armed conflict situations globally. By the same token, efforts at addressing armed conflict must also take into account effective engagement with armed groups. Apart from the use of crude violence, the presence or existence of these groups has the potential to undermine state

\footnotetext{
${ }^{14}$ Martha Nsen Foy, “The Plight of Women and Children in Africa's Armed Conflict Theatre with Special reference to Sierra Leone" (PhD diss., University of Ibadan), 134.

${ }^{15}$ The point being made here is that controlling the mass violence perpetrated by armed groups against civilians is more difficult than that of the state because while the state may be forced, through the threat of sanctions, to use reasonable violence by the international community, this does not apply to armed groups in most cases because they are not recognized in the international community. For Instance, President Donald Trump bombed a military base in Syria to retaliate the alleged Assad's use of chemical against Syria civilians by Assad. This may have been difficult to carry out on armed groups.

${ }^{16}$ Gareth Evans, The Responsibility to Protect: Ending Mass Atrocity Crimes Once and for All (Washington, DC: The Brookings Institution, 2009), 1-369; Lawrence Woocher, "The Responsibility to Prevent: Towards a Strategy," in Routledge Handbook on the Responsibility to Protect, ed. Andy Knight and Frazer Egerton (London: Routledge, 2011), 22-35.

${ }^{17}$ Alex Bellamy, "Mass Atrocities and Armed Conflict: Links, Distinctions, and Implications for the Responsibility to Prevent," Policy Analysis Brief: Innovative Approaches to Peace and Security from the Stanley Foundation (Muscatine: The Stanley Foundation, February 2011), 1-20, accessed November 25, 2018, https://www.stanleyfoundation.org/ publications/pab/BellamyPAB22011.pdf.
} 
and peacebuilding efforts. Therefore, effective engagement with armed groups by states is not only necessary to prevent the commission of mass atrocities by armed groups against civilians, but to also promote effective state- and peace-building in conflict and post-conflict societies.

There are three fundamental ways to respond to armed groups within a state. One is the use of coercive power. In this case, the state uses its security forces and, particularly the military to crush any uprising from NSAGs. This appears to have been the most popular state response to armed groups especially since the 9/11 attack on the United States. However, this approach has proven to be bloody with the potential to escalate violence and facilitate grave humanitarian costs for civilian populations. Second, the use of a non-coercive approach such as the use of dialogue, amnesty programs, or negotiating with armed groups. The third way involves the implementation of an eclectic approach or what has been have referred to as the carrot and stick approach. This is a blend of both coercive and non-coercive approaches. The question then is which of these approaches is best to engage armed groups? In a study carried out in 2008 by Audrey Curth Cronin entitled Ending Terrorism: Lessons for Defeating Al Qaida, Cronin opined that the best approach to ending the activities of armed groups is the non-coercive approach. ${ }^{18}$ She underscores the counterproductive nature of a military approach because it has the result of driving armed groups underground and propels them to use guerrilla tactics against the military. As a consequence, a coercive approach prolongs armed conflict because armed groups are rarely defeated by the military in such situations. Cronin ended up by advising the United States of America to use non-coercive approach in her engagement with al Qaida. Similarly, in 2008, Seth, Martin and Libicki carried out a study on how armed groups have ended from 1968 to $2006 .{ }^{19}$ The research concluded that all armed groups eventually end, but how they end differs based on the goal sought by the group. The study discovered the ways in which armed groups leave armed violence have followed similar patterns, which include joining the political process of the state,the arrest and killing of key members of the group by local police and the intelligence agencies of the state, the victory of the armed group over the state, and the use of military force of the state against the group. The study held that the use of military force is the least productive avenue and the use of a non-coercive approach is the most productive. Other studies, such as the worl of Crenshaw, ${ }^{20}$ Stedman, ${ }^{21}$ Dudouet, ${ }^{22}$ and Hofman and Schneckener, ${ }^{23}$ have also pointed to the effectiveness of a non-coercive approach in the engagement of NSAGs to reduce or totally end non-state armed groups' violent action. The world continues to witness an increase in the use of a non-coercive approach to state engagement with armed groups. Even the United States of America, which has been promoting a global war against terrorism, began to apply a non-coercive approach, particularly under the previous administration of President Barrack Obama. Nigeria, too, has used a non-coercive approach (referred to as the Amnesty Program) in her engagement of Niger Delta militant groups while also considering doing the same to the Boko Haram militants in the North East. The problem, however, is that if the state must use a non-coercive approach, how should it be implemented so as to promote sustainable peace? This remains a critical question yet to be answered comprehensively. This paper will answer this question by using the case study of the Nigeria and her use of a non-coercive approach in the engagement of armed groups in the Niger Delta region. The central argument of the paper

\footnotetext{
${ }^{18}$ Audrey Kurth Cronin, Ending Terrorism: Lesson for Defeating Al-Qaeda (Oxon: Routledge, 2008).

${ }^{19}$ Seth G. Jones and Martin C. Libicki, “How Terrorist Group End: Lesson for Countering Al Qa'ida” (Santa Monica: RAND Corporation, 2008), accessed November 25, 2016, https://www.rand.org/content/dam/rand/pubs/ monographs/2008/RAND MG741-1.pdf.

${ }^{20}$ Martha Crenshaw, "Why Violence is Rejected or Renounced: A Case Study of Oppositional Terrorism," in A Natural History of Peace, ed. Thomas Gregor. (Nashville: Vanderbilt University Press, 1996).

${ }^{21}$ Stephen John Stedman, "Spoiler Problem in Peace Process," International Security 22, no. 2 (1997), 5-53. DOI: $\underline{10.2307 / 2539366}$

${ }^{22}$ Veronique Dudouet, "Mediating Peace with Proscribe Armed Groups," USIP Special Report 239 (Washington, DC: United States Institute of Peace, May 2010), accessed October 28, 2018. https://www.usip.org/sites/default/files/ SR239Duduoet.pdf.

${ }^{23}$ Claudia Hofmann and Ulrich Schneckener, "How to engage Armed Groups? Reviewing Options and Strategies for Third Parties," in Security and Peace: Security Apparatuses in fragile and Authoritarian States, ed. Michael Brzoska, et al (Bonn: Simon Koschut, 2011), 57-72.
} 
suggests that adopting a non-coercive approach in engaging armed groups in situations of armed conflict is not enough to promote sustainable peace in post-conflict situations. The adoption of a non-coercive engagement must comprise society-wide peacebuilding that is not only integrative, but also promotes reconciliation and addresses the core problems and root causes of the grievances, which morphed into open hostility and armed conflict.

\section{A Non-Coercive Approach and Peacebuilding: Establishing the Link}

The concept of peacebuilding can be traced to Boutros Boutros-Ghali's Agenda for Peace, which was released in 1992. In the piece, Boutros-Ghali introduced what he called Post-Conflict Peacebuilding. Post-Conflict Peacebuilding was simply defined as any effort to construct a new environment that makes a relapse back to conflict impossible. Boutros-Ghali tried to differentiate Post-Conflict Peacebuilding from other concepts such as peacekeeping and peacemaking and also linked them together, opining

peacebuilding should be viewed as counterpart of preventive diplomacy which seeks to avoid the breakdown of peaceful conditions. When conflict breaks out, mutually reinforcing effort at peacemaking and peacekeeping come to play. Once these have achieved their objectives, only sustained, cooperative work to deal with underlying economic, social, cultural and humanitarian problems can place an achieved peace on a durable foundation. ${ }^{24}$

For Boutros-Ghali, peacebuilding was efforts to make a fragile peace durable through peacemaking and peacekeeping. This is why he termed the phrase post-conflict peacebuilding. However, John Paul Lederach outlines the concept of peacebuilding more clearly. In his book titled Building Peace: Sustainable Reconciliation in Divided Societies, ${ }^{25}$ Lederach notes the essence of peacebuilding is to promote sustainable peace, which is not only limited to brokering a ceasefire, negotiating a peace agreement or implementing a multifaceted peace accord, but also involves making sure long time antagonists lay down their arms, and achieving an enduring reconciliation framework by crafting a society-wide network of relationships and putting in place mechanisms that promote justice and address the root cause of enmity. Lederach began his explanation by looking at contemporary armed conflict globally and examining the characteristics of deeply divided societies. He observed that contemporary armed conflicts are often caused by the failure of governing structures to address the fundamental needs of the people, to ensure the equitable distribution of wealth and benefit, which make identification with a particular group so attractive and salient in a given setting. This can result in the formation of armed groups by aggrieved parties to pursue their demands after several periods of peaceful agitation have not yielded any meaningful results. More specifically, the political structures within which people operate often provide little opportunity for the non-violent pursuit of socio-economic and political objectives. Lederach also detailed the characteristics of deeply divided societies that often promote armed conflict. These characteristics include a narrowing of identity couched in clan, ethnicity, religion or geographic/ regional affiliation, or a mixture of these that promote distrust, hatred and fear, which often fuel conflict and, particularly between conflicting groups living in close proximity. What Lederach was seeking to underscore is the issues that lead to the outbreak of armed conflict are typically related to injustice, inequality, and unmet needs. In order to address these issues, therefore, conscientious efforts must be made that involve employing a non-coercive approach such as dialogue and reconciliation. Dialogue and reconciliation processes facilitate truth (acknowledgment of wrongs and validation of painful loss and experiences leading to clarity); mercy (acceptance, forgiveness, compassion, healing); justice (the search for individual and group rights, for social restructuring, and for restitution), all of which are linked to sustainable peace. ${ }^{26}$ Rwanda and South African can be highlighted as success stories of how reconciliation and dialogue processes have been used to bring about peace in situations of intense armed conflict. In these two countries, acknowledgement

\footnotetext{
${ }^{25}$ John Paul Lederach, Building Peace: Sustainable Reconciliation in Divided Societies (Washington, DC: United States Institute for Peace Press, 1998).

${ }^{26}$ Ibid., 29.
} 
of wrong doing, healing by those affected by violence, and restitution through dialogue ushered in peace.

The point being made here is that contemporary armed conflicts are caused by the structural problems of contemporary societies and, particularly deeply divided ones. These problems cannot be addressed through the implementation of a one-dimensional non-coercive approach. Rather, it is essential a multidimensional non-coercive approach is employed that promotes dialogue and negotiation to address the roots of the conflict. These are also necessary attributes that promote reconciliation and peacebuilding. Any move short of this, even if it is non-coercive to the extent that it does not involve the use of military force, is a false attempt to build peace. Crucially, any such non-coercive engagement that is not premised on holistic peacebuilding may have the potential to deepen a conflict situation, making it worse. The only way to address mass violence is through policies that advance reconciliation and comprehensive peacebuilding.

\section{The Development of the Niger Delta Armed Conflict in Nigeria}

The Niger Delta crisis, that later developed into an armed confrontation, began as agitation for political recognition within the Nigerian state during the pre-colonial period. Political elites from the region used party politics, dialogue, and several other peaceful means to convey their dissatisfaction. As Nigeria was moving towards independence, the British colonial authorities set up a commission of inquiry known as the Henry Willink Commission to look into the fears of minorities and make recommendations. However, the recommendations made by the commissionthe need for fundamental human rights and the establishment of the Niger Delta Development Board- did not address the central concern of the Niger Delta people, which was adequate political representation. In 1963, the Mid-Western region was carved out of the then Western region, but it was not enough to address the issue of political recognition of the Niger Delta people as the Igbocontrolled political party, National Council of Nigerian Citizens (NCNC) dominated the greater part of the core Niger Delta region.

The discovery of oil in commercial quantity in the 1970s further escalated the perceived negligence and persistent development problem of the Niger Delta, which was compounded by issues of environmental degradation that threatened the survival of the region's people. The discontent of the people of the Niger Delta increased because while the benefits of crude oil exploration go to the federal government, the associated consequences of oil exploration are borne solely by the people. The livelihood of the people, especially land (farming) and rivers (fishing) have been destroyed as a result of oil exploration. This intensified the agitation of the people which was expressed in non-violent forms of engagement, including negotiation, meetings, litigation, and peaceful protest. ${ }^{27}$ However, all of these methods of engagement by the people were met with a scorched earth approach by the government. This resulted in the development of a radical response and the adoption of violent confrontation as the preferred means of engagement. Armed confrontation in the Niger Delta crisis started in 1998 when the Ijaw Youth Council convened a meeting of Ijaw youths at Kaiama to discuss the impoverishment of the Niger Delta region by the federal government and oil companies. ${ }^{28}$ In 2006, armed struggle for resource control took on another dimension with the establishment of the Movement for the Emancipation of the Niger Delta (MEND), as the umbrella body for all militant groups in the Niger Delta region, especially of Ijaw extraction. The aim of the group was to carry out increased and coordinated attacks on oil installations with the view to crippling Nigeria's oil-dependent economy. Between 2006 and 2009, the armed groups wreaked havoc on oil installations leading to a significant drop in oil exploration and a fall in the revenue profile of the Nigerian state.

\footnotetext{
${ }^{27}$ For extensive discussion of these non-violent approaches and how they have failed, see Christopher B.N. Ogbogbo, "Niger Delta Peoples and the Resource Control Conflict, 1960-1995: An Assessment of Conflict Handling Styles," in Perspectives on Peace and Conflict in Africa: Essays in Honour of General (Dr.) Abdulsalami A. Abubakar, ed. Isaac Olawale Albert (Abuja: John Archers Press, 2005), 170-181.

${ }^{28}$ Saheed Babajide Owonikoko, "Kidnapping in Pre- and Post- Amnesty Niger Delta, Nigeria," International Journal of Peace and Conflict 3, no. 2 (2016).
} 
Amnesty Program: The Non-Coercive Approach to Armed Conflict in the Niger Delta

Since 1998, when armed struggle was declared on the Nigerian state by Niger Delta armed groups, the federal government has responded by deploying heavily armed military personnel to the region. Most of these military outfits have been coded as Joint Task Forces. However, armed insurrection continued to be intense with serious implications on oil exploration and revenue for the Nigeria state. By 2009, oil exploration had drastically plummeted. As a result of the concerted efforts of the armed groups, oil exploration fell from 2.6 million barrels per day to about 700,000 in the third quarter of 2009 prior to the implementation of the amnesty program. This made the federal government consider an alternative approach to the management of the Niger Delta crisis. The alternative approach taken by the government was the implementation of an amnesty program on the Niger Delta militants. There were several problems with the implementation of the amnesty program by the federal government in the Niger Delta region. Apart from deliberate attacks on oil installations, militant groups were involved in a series of other anti-state activities such as kidnappings, illegal oil bunkering, the drug trade, piracy, and attacks on government security agents. The target of the federal government was to increase oil exploration and revenue. The thinking of the Nigerian federal government was if armed groups ceased to exist, all other activities associated with them would disappear. Thus, the amnesty program was couched in disarmament, demobilization and reintegration (DDR). Disarmament meant every militant was required to submit their weapons and demobilization referred to the disengagement of militant from their various armed groups, while reintegration involved training them, and returning them to their communities. A total of 30,000 militants were disarmed during the three phases. The total number of militants disarmed and the caliber of weapons submitted gave the impression the program was successful.

There were many problems with the implementation of the amnesty program. First, the program was imposed on the armed groups from the federal government. As Albert ${ }^{29}$ has argued, the concept of amnesty suggests a state of asymmetry in power relations between conflict parties, in which the victorious side delivers an amnesty package as part of post-conflict peacebuilding strategies. On the other hand, it can also come when both sides to the conflict acknowledge they have been hurt by the conflict and require restitution. Therefore, to restore healthy relations, all the parties will confess what they did to each other and ask for forgiveness. Forgiveness was supposed to be the amnesty. In this case, however, those who introduced the amnesty program (the Nigerian federal government) were not victorious over the militant groups. Nor were there any feelings of guilt or hurt or the need for restitution felt by either the Niger Delta militants or the federal government. However, the federal government packaged the amnesty program as something benevolent towards the militant groups. Secondly, there was no any clarity (truth), healing (mercy), and restitution (justice) sought before the implementation of the amnesty program. There were many occasions when both government security forces and militants were involved in mass atrocities, which have imbued hatred and distrust among civilians. The most obvious example was the sacking of Odi, a small Ijaw village in Kolokuma/Opokuma, a local government area of Bayelsa State, by government military forces in 1999. Report suggested members of Egbesus Boys of Africa (EBA) abducted seven policemen, including a deputy commissioner dispatched to Odi on an official assignment. Subsequently, they abducted and killed three soldiers traveling along East-West road. The inability of the government of Bayelsa state to find and charge the culprits led the President, Chief Olusegun Obasanjo, to deploy military personnel. The deployed military personnel wreaked havoc on the residents of the village in a manner so unprecedented in the history of Nigeria that it was deemed to have constituted genocide against the Ijaw people. The report of twenty-nine human rights organizations, environmental rights groups, and civil society movements that had visited the village on December 8, 1999, read

so ruthless, savage and thorough was the operation that it could have been intended to achieve a genocidal outcome... We received reports of mass burial, mass cremation, and the

${ }^{29}$ Isaac Olawale Albert, “Stakeholders' Engagement with the First Phase of the Niger Delta Amnesty Deal in Nigeria," Peace Studies and Practice 1, no. 4 (2015), 388-402. 
disembowelment and mass dumping of corpse in River Nun. Two weeks after the operation, the stench of decomposing bodies dumped into various creeks could still be perceived from one kilometer to the town. We saw so many corpses as we drove along. The body of an old man, still clutching firm to a copy of the Holy Bible, lay decomposing in a pond behind the Anglican Church, a chilly testimony to the scorch-earth objective of the invading troops contrary to the officially declared objectives of the mission: to arrest the hoodlums who allegedly killed some policemen. ${ }^{30}$

The report added,

so complete was the destruction that crops were razed, yam barns were burnt, garri processing plants were willfully wrecked, canoes were set ablaze, and every house in the entire community with the exception of the First Bank, a Community Health Centre and the Anglican Church, were burnt down. No aspect of the Community's existence was spared. Places of worship and other sacred places, including sacred forests and groves, churches, ancestral homes and burial places were demolished. We received report that the soldiers looted many of the buildings and made away with valuables before setting them ablaze. We saw no single livestock, poultry and other domestic animal except a stray cat. The community of 60,000 inhabitants had fled into the forest or been arrested or killed. ${ }^{31}$

The graffiti inscriptions left behind by the military personnel showed that the act was deliberately orchestrated and targeted at the Ijaw. Such inscriptions include: "we will kill all Ijaws," "Shame to the Ijaw people," "Odi where is your pride?," "learn a lesson, visit Odi," "Where is Egbesu," "So Odi youths, is this the end of Egbesu in Odi Village?," "Thou will serve God the maker of Heaven and Earth and not Egbesu," "This land is for Soja, not for Ijaw," "You bagers of Odi (Egbesu) should be very careful with the living God," "The wicked shall never go unpunished," "The bible said what shall an Odi man gain after losing his soul, lost the world and his home," "Hi what is going on? Man, how far? What about Odi, the HQ of the so called Egbesu?" "Who born Odi, Na Egbesu," "Silence! No noise. Egbesu is dead," "Next time, even the trees will not be spared," "Say no to Egbesu, yes to Soldiers," "Who is more important? Egbesu or Soldier? Soldier," "Bayelsa will be silent forever," among others. ${ }^{32}$ This had created hatred between the people and the government that needed to be addressed before amnesty was declared.

Third, the amnesty program was not preempted by any form of negotiation between the Niger Delta people and the federal government. As a matter of fact, the implementation of amnesty was supposed to be the concluding part of the reconciliation program implemented to address the Niger Delta crisis. As Ledum Mittee commented,

the amnesty was supposed to be the end and not the beginning... I have my difficulty with the way they have presented amnesty as a solution in itself. They seem to be saying that we are not going to prosecute some people if they drop their arms and then that will bring peace. Anybody who thinks that way, must be dreaming. We have got to a situation where people do not trust the government when it comes to the issue of Niger Delta. And to change this view, you must do something dramatic. ${ }^{33}$

Fourth, the program did not address the many problems of the Niger Delta region that had fueled the Niger Delta crisis, inclusive of unemployment, poverty, environmental degradation, and so forth. The thinking of the government was that the greater challenge to peace and security was militant group activity and that once they were removed from the equation, peace would return. Therefore, the government concentrated on the militants that emerged from the Niger Delta crisis, while the core issues and root causes of the Niger Delta crisis were ignored. Even the DDR

\footnotetext{
${ }^{30}$ Constitutional Right Journal cited in Owonikoko, Kidnapping, 242.

${ }^{31}$ Ibid., 242.

32 Saheed, Kidnapping, 276.

${ }^{33}$ Cited in Albert, Stakeholders' Engagement, 391.
} 
program organized for the militants was implemented haphazardly. The initial phase of the DDR program, disarmament, was successful due to the large turnout of militants who submitted their arms. The second and third phases of the DDR agenda, especially the reintegration stage, which is an essential component of the program, was not implemented effectively. ${ }^{34}$ The way and manner in which the amnesty program was implemented underscores that peace was bought, but not built. The leadership of the various militant groups were given huge contracts running in the billions of naira (Nigerian currency) to accept the amnesty program, to submit their arms, and encourage their followers to do same. ${ }^{35}$ On the other hand, militant group foot soldiers enrolled in the amnesty program have been given a monthly stipend of hundred and eighty dollars from 2009 to date. This has encouraged militants to accept amnesty and submit a fraction of their arms to the state.

What effect did this have on peace and security in the Niger Delta and Nigeria more broadly? The introduction of the amnesty program reduced armed conflict- the confrontation between state security personnel and the militant group. It also led to an immediate increase in oil exploration and the revenue profile of the Nigerian state. However, there was a significant increase in crimes, including piracy, kidnapping, armed robbery, and oil bunkering, among others. ${ }^{36}$ Looking at the circumstances under which the militant warlords increased their personal wealth through the awarding of contracts and the manner in which their foot soldiers have been paid stipends without any corresponding assignment, in the midst of many poor and unemployed youths, the implementation of amnesty made militancy attractive to the youths of the region and promoted a sense of impunity. In the words of one student from the Niger Delta University, [jokingly] “... after my first degree I will go and join a militant group in my village. After all, there are no jobs out there and one has to make a living. Maybe [the] government will call me, too, for amnesty...." ${ }^{\prime 37}$ This statement is simple but loaded and shows the perception of many non-militants, but unemployed youths in the Niger Delta region. Firstly, it highlights how the implementation of the amnesty program was more of an incentive to indulge in violence than a solution to armed violence in the Niger Delta region. Secondly, it also shows in spite of the implementation of the amnesty program, militancy and militant groups still remain in the Niger Delta region. What kept militancy low in the early period of the program was the then President of Nigeria, Dr. Goodluck Ebele Jonathan, was from the Niger Delta. As soon as he was defeated in 2015, militancy and armed conflict resumed. Between January 2016 and July 2016, a new militant group calling itself the Niger Delta Avenger (NDA) carried out thirty-four deadly attacks on oil installations. These attacks crush the Nigerian oil-based economy and pushed the country back into recession. ${ }^{38}$

\section{Ending Boko Haram Atrocities: Lesson from the Niger Delta Amnesty}

As the tempo of armed insurrection was abating in the Niger Delta in 2009, Boko Haram commenced its atrocities in the North East region of Nigeria. Although insurgency in the Niger Delta has been largely motivated by resource control, the Boko Haram insurgency is motivated by religious (especially Islamic) fundamentalism. ${ }^{39}$ The Boko Haram insurgency and responses to

\footnotetext{
${ }^{34}$ For an extensive review of the DDR process of the amnesty programme, see Judith Burdin Asuni, "Consequences of the Forgotten (or Missing) ' $\mathrm{R}^{\prime}$," in Monopoly of Force: The Nexus of Disarmament, Demobilisation and Reintegration (DDR) and Security Sector Reform (SSR) ed. Melanne A. Civic and Michael Miklaucic (Washington, DC: Progressive Management Publication, 2011), 155-172.

${ }^{35}$ Ibid., 159.

${ }^{36}$ Saheed Babajide Owonikoko, "An Assessment of Government Engagement with Armed Groups in the Niger Delta Region" (PhD diss., University of Ibadan, Nigeria, 2016).

${ }^{37}$ Ibid., 74 .

${ }^{38}$ Saheed Babajide Owonikoko, “"Mutual Hurting Stalemate and Sense of a Way Out”: Interrogating the Niger Delta Presidential Amnesty Programme in Yar'Adua's Nigeria," in Governance, Security and Peacebuilding in the Niger Delta: Essays in Honour of Kingsley Burutu Otuaro, ed. Jarikre Mathias et al. (Ibadan: Zenith Book House, 2018), 133.

${ }^{39}$ Dominic Nathaniel Danjibo, "Islamic Fundamentalism and Sectarian Violence: The 'Maitatsine' and 'Boko Haram' Crises in Northern Nigeria" (paper presentation, IFRA Conference, University of Ilorin, Ilorin, Nigeria, 2010; Mohammed Kyari, "The message and methods of Boko Haram," in Boko Haram: Islamism, Politics, Security and the State in Nigeria, ed. Marc-Antoine Pérouse de Montclos, West African Politics and Society Series, Vol. 2 (Leiden: African Studies Centre, 2014).
} 
it (both government and local) have resulted in the commission of atrocities. While Boko Haram attacks on Christians have caused inter-religious rivalry in most communities in the North East, ${ }^{40}$ government security agents have also alleged been involved in unlawful killings, illegal detentions, dragnet arrests, intimidation, extortion, and other human rights abuses and atrocities. Various reports from Amnesty International and Human Right Watch have accused Nigerian security agencies, especially the army, of extra-judicial killings and torture of both Boko Haram and nonBoko Haram members. ${ }^{41}$ These have contributed significantly to an escalation of the conflict. Local responses to the insurgency, including the formation of civilian joint task forces, vigilante groups, and the hunters are not helping the matter. While people see these security outfits as necessary and have applauded their actions against Boko Haram, their activities have only served to promote retaliation, vengeance, and self help as most people who join these groups are those whose relatives have been killed or maimed by members of Boko Haram. Their aim of joining is not only to protect themselves and their immediate community, but to avenge attacks on their relative. ${ }^{42}$

Taking a cue from the perceived success of the use of a non-coercive approach in the Niger Delta region, the federal government of Nigeria has shown the readiness to also grant amnesty to the members of Boko Haram to end insecurity, terrorism, and armed conflict in the North East Nigeria. The first attempt to grant amnesty to Boko Haram members was during the presidency of Goodluck in 2013. After refusing the call from northern elites to grant amnesty to Boko Haram, citing the facelessness of the group as a reason, he later agreed. A committee was set up to look into the feasibility of the program. However, in a thirty minute video released a few days after, Shekau, the leader of the group refused amnesty noting: "FG [the federal government], not us needs Amnesty." 43 The issue reappeared in August 2015 when President Buhari was reported to have approved amnesty for Boko Haram. ${ }^{44}$ Apart from the federal government, the Borno State government under Ibrahim Shettima has repeatedly called for the need to use a political, noncoercive approach to end Boko Haram terrorism. During the inauguration of his regime on May 29, 2015, Shettima pledged to pursue amnesty for members of Boko Haram who were ready to deradicalize, noting he would lobby the federal government to do so. However, lessons must be learned from the Niger Delta amnesty program when considering the implementation of the Boko Haram Amnesty program. The reconciliation process must be total and should not only concentrate on Boko Haram members. Furthermore, it should be preceded by dialogue focused on truth, healing, and restitution. It must be an amnesty program targeted towards building rather than buying peace in order to diminish the potential for hostilities and armed conflict to reignite.

\section{Conclusion}

As cases of armed conflict between government forces and non-state armed groups continue to increase globally and, particularly in developing countries, there may also be an increase in cases of mass atrocities committed globally. The use of a non-coercive approach will continue to be a strategic option for the modern state to reduce armed violence and mass atrocity crimes perpetrated by nonstate armed groups and prevent a prolonged stalemate between conflict parties. In addition to the two cases included in this study, the Colombian case concerning the negotiated settlement between

\footnotetext{
${ }^{40}$ For instance, in communities and local government areas seized and controlled by Boko Haram in Adamawa State such as Mubi, Michika and Madagali, serious inter-religious disharmony is present between Christian and Muslim inhabitants. Christians and Muslims do not trade in the same markets and on the same days. While Christians trade on Saturdays, Muslims trade on Sundays.

${ }_{41}$ "Spiraling Violence: Boko Haram Attacks and Security Force Abuses in Nigeria," Human Rights Watch, October 11, 2012, accessed January 24, 2018, https://wwwhrw.org/sites/default/file/report/nigeria1012webwcover.pdf; "Stars on their Shoulders. Blood in their Hands: War Crimes Committed by the Nigerian Military," Amnesty International, June, 2015, accessed January 24, 2018, https://www.amnesty.org/download/documents/AFR4416572015ENGLISH.PDF.

${ }^{42}$ Jude Momodu and Saheed Babajide Owonikoko, “Non-State Security Groups and Counterterrorism Campaign Against Boko Haram in Northeastern Nigeria" (paper presentation, University of Maroua, Maroua, Cameroon, May 2017).

43 “Nigeria: FG, Not Us needs Amnesty- Boko Haram," Vanguard News, April 12, 2013, accessed April 19, 2017, https:// www.vanguardngr.com/2013/04/fg-not-us-needs-amnesty-boko-haram/.

${ }^{44}$ Kayode Sesan and Kingsley Kanayo, "President Buhari Approves Amnesty for Boko Haram," Breaking Times, August 6, 2015, accessed April 19, 2017, https://thebreakingtimes.com/buhari-approves-amnesty-for-boko-haram/.
} 
the government of Colombia and FARC ${ }^{45}$ that has gradually put an end to over five decades of armed conflict is a case in point. The Colombian government accord with FARC also served as the catalyst for the government to begin negotiations with the ELN. ${ }^{46}$ While a non-coercive approach to the management of armed groups and armed violence in contemporary contexts of armed conflict may be desirable, its implementation must be devoid of the perception that militants can be simply pacified or rewards for displays of non-state armed violence. When a non-coercive approach is implemented to pacify non-state armed groups, it may help to stem the tide of armed conflict and violence in the short term, but it may also increase crime and convey an unintended message to the people that the state is weak or rewards violence. This was the case in the Niger Delta region whereby the government imposed amnesty to pacify militants, which reduced the armed conflict, but increased crime significantly and led to the emergence of new militant groups and warlords. ${ }^{47}$ It was also for the same reason the peace deal struck between the Colombian government and FARC was rejected by the Colombian people in a referendum as the people felt the deal was too forgiving to FARC given the atrocities perpetrated by the group that had led to more than 260,000 deaths, the disappearance of tens of thousands, and the displacement of over 6 million people over the five decades long war. ${ }^{48}$ Evidently, a non-coercive approach implemented to pacify non-state armed groups cannot engender sustainable peace and security in countries experiencing non-state armed, internal conflict. There is a need, therefore, to rethink the implementation of non-coercive approaches to building sustainable peace. A non-coercive approach to promote sustainable peace must be conscientiously implemented to heal the wounds created during the period of violent conflict while also addressing political and socio-economic challenges undergirding grievances that fostered and promoted armed conflict. This may involve strengthening institutions and state governance structures, promoting transparency and accountability in government, tackling poverty, unemployment, and other structural problems in the polity. Without more holistic policies of reconciliation and peacebuilding, amnesty programs themselves will not end mass violence.

\section{Bibliography}

Achebe, Chinua. There was a Country: A Personal History of Biafra. London: Penguin Book, 2012.

Albert, Isaac Olawale. "Stakeholders' Engagement with the First Phase of the Niger Delta Amnesty Deal in Nigeria." Journal of the Society for Peace Studies and Practice 1, no. 4 (2015), 388-402.

Amnesty International. "Stars on their Shoulders, Blood in their Hands: War Crimes Committed by the Nigerian Military." June 2015. Accessed October 28, 2016. https://www.amnesty.org/ download/documents/AFR4416572015ENGLISH.PDF.

Asuni, Judith Burdin. "Consequences of the Forgotten (or Missing) ' $\mathrm{R}^{\prime}$. . In Monopoly of Force: The Nexus of Disarmament, Demobilisation and Reintegration (DDR) and Security Sector Reform (SSR), edited by Melanne A. Civic and Michael Miklaucic, 155-172. Washington, DC: Progressive Management Publications, 2011. DOI: 10.21236/ada546586

Barkawi, Tarak. "On the Pedagogy of Small War." International Affairs 80, no. 1 (2004), 19-37

Bellamy, Alex. "Mass Atrocities and Armed Conflict: Links, Distinctions, and Implications for the Responsibility to Prevent." Policy Analysis Brief. Muscatine: The Stanley Foundation, 2011.

Lewis, Wave, ed. Low intensity Conflict in the Third World. Alabama: Air University Press, 1988.

Caicedon, Jerome Delgado. "Paramilitary Groups and National Security: A Comparison Between Cambodia and Sudan." African Centre For The Constructive Resolution of Disputes. Conflict trends, 4 (2009), 3-12.

\footnotetext{
${ }^{45}$ Known as Revolutionary Armed Forces of Colombia. It had over 7,000 fighters.

${ }^{46}$ Known as National Liberation Army, ELN is a guerrilla rebel group with over 1,500 fighters. It was labelled as a terrorist group by the United States and the European Union. This group is believed to have bombed the Colombian electricity and oil infrastructure, extorted and kidnapped hundreds of people during its over five decades war with the Colombian government.

${ }^{47}$ Owonikoko, An Assessment of Government Engagement.

48 "Colombia and ELN Rebels to Return to Peace Negotiations," Aljazeera, May 6, 2017, accessed October 28, 2018, https:// www.aljazeera.com/news/2017/05/colombia-eln-rebels-return-peace-negotiations-170507051113249.html; "Can Peace in Colombia be Saved?: Voters Reject the Historic Deal to End Half a Century War with FARC Rebels," Aljazeera, October 3, 2017, accessed October 28, 2018, https://www.aljazeera.com/programmes/insidestory/2016/10/peacecolombia-saved-161003182626940.html.
} 
Callwell, Charles E. Small Wars: Their Principles and Practice. 3rd ed. Lincoln: University of Nebreska Press, 1994.

"Can Peace in Colombia be saved? Voters Reject the Historic Deal to End Half a Century War with FARC Rebels." Aljazeera, October 3, 2017. Accessed October 28, 2018. https://www. aljazeera.com/programmes/insidestory/2016/10/peace-colombia-saved-161003182626940. $\underline{\mathrm{html}}$.

"Colombia and ELN Rebels to Return to Peace Negotiations." Aljazeera, May 6, 2017. Accessed October 28, 2018. https://www.aljazeera.com/news/2017/05/colombia-eln-rebels-returnpeace-negotiations-170507051113249.html.

Crenshaw, Martha. "Why Violence is Rejected or Renounced: A Case Study of Oppositional Terrorism." In A Natural History of Peace, edited by Thomas Gregor, 249-273. Nashville: Vanderbilt University Press, 1996.

Creveld, Martin Van. The Transformation of Wars. New York: The Free Press, 1991.

Cronin, Audrey Kurth. Ending Terrorism: Lesson for Defeating Al Qaida. Oxon: Routledge, 2008.

Danjibo, Dominic Nathaniel. "Islamic Fundamentalism and Sectarian Violence: The 'Maitatsine' and 'Boko Haram' Crises in Northern Nigeria." Paper presented at IFRA Conference, University of Ilorin, Ilorin, Nigeria, 2010.

Dean, David J, ed. Low Intensity Conflict and Technology. Alabama: Air University Press, 1986.

Dudouet, Veronique. "Mediating Peace with Proscribe Armed Groups." USIP Special Report 239, May, 2010. Washington, DC: United States Institute of Peace. Accessed October, 2018. https://www.usip.org/sites/default/files/SR239Duduoet.

Evans, Gareth. The Responsibility to Protect: Ending Mass Atrocity Crimes Once and for All. Washington, DC: The Brookings Institution, 2009.

Foy, Martha Nsen. "The Plight of Women and Children in Africa's Armed Conflict Theatre with Special reference to Sierra Leone." PhD diss., Institute of African Studies, University of Ibadan, 2007.

Ghali, Boutros Boutros. An Agenda for Peace: Preventive Diplomacy, Peacemaking and Peacekeeping. Report of the Secretary-General pursuant to the Statement adopted by the Summit meeting of the Security Council. January, 31, 1992. Accessed October 2018. http://www.un.org/en/ sc/repertoire/89-92/Chapter\%208/GENERAL\%20ISSUES/Item\%2029 Agenda\%20for\%20 peace .pdf. DOI: 10.1177/004711789201100302

Hammond, Grant T. "Low Intensity Conflict: War by another name." Journal of Small Wars and Insurgencies, 1 no. 3 (1990), 226-238. DOI: 10.1080/09592319008422957

Harris, Peter and Keilly Ben, eds. Democracy and Deep-Rooted Conflict: Option for Negotiators. Stockhom: International Institute for Democracy and Electoral Assistance, 1998.

Hofman, Claudia and Ulrich Schneckener. "How to engage Armed Groups? Reviewing Options and Strategies for Third Parties." In Security and Peace: Security Apparatuses in fragile and Authoritarian States, edited by Michael Brzoska, 57-72. Bonn: Simon Koschut, 2011. DOI: 10.5771/0175-274x-2011-4-254

Human Rights Watch. "Spiraling Violence: Boko Haram Attacks and Security Force Abuses in Nigeria." October 2012. Accessed October 28, 2018. https://wwwhrw.org/sites/default/file/ report/nigeria1012webwcover.pdf.

Jones, Seth G. and Martin C. Libicki. How Terrorist Group End: Lesson for Countering Al Qaida. California: RAND Corporation, 2008.

Kaldor, Mary. New and Old Wars: Organized Violence in Global Era. Oxford: Polity Press, 1999.

Kalevi, Holsti. The State, War and the State of War. Cambridge, UK: Cambridge University Press, 1996.

Kalyvas, Stathis and Matthew Adam Kochas. "Ethnic Cleavages and Irregular War: Iraq and Vietnam." Politics and Society 35, no.2 (2007), 183-223. DOI: 10.1177/0032329207302403

Kessler, Glenn and Colum Lynch. "U.S. Calls Killings in Sudan Genocide: Khartoum and Arab Militias are Responsible." Washington Post, September 10, 2004. Accessed October 28, 2018. http://www.washingtonpost.com/wp-dyn/articles/A8364-2004Sep9.html.

Kinross, Stuart. "Clausewitz and Low intensity Conflict." Journal of Strategic Studies 27, no. 1 (2003), 35-58. 
Kober, Avi. "Low Intensity Conflict: Why the Gap between Theory and Practice." Defense and Security Analysis 18, no.1 (2002), 15-38. DOI: 10.1080/07430170120113712

Kyari, Mohammed. "The Message and Methods of Boko Haram." In Boko Haram: Islamism, Politics, Security and the State in Nigeria, West African Politics and Society Series, Vol. 2, edited by Marc-Antoine Pérouse de Montclos, 9-32. Leiden: African Studies Centre, 2014.

Lederach, John Paul. Building Peace: Sustainable Reconciliation in Divided Societies. Washington: United States Institute for Peace Press, 1999.

Lind, Williams S., Keith Nightengale, John F. Schmitt, Joseph W. Sutton and Gary I Wilson. "The Changing Face of War into the Fourth Generation." Marine Corp Gazette 85, no. 11 (October 1989).

Manwaring, Max, ed. Uncomfortable War: Towards A New Paradigm of Low Intensity Conflict. Boulder: Western Press, 1991.

Momodu, Jude and Saheed Babajide Owonikoko. "Non-State Security Groups and Counterterrorism Campaign Against Boko Haram in Northeastern Nigeria." Paper presented at a conference at the University of Maroua, Maroua, Cameroon, May 2017.

Ogbogbo, Christopher B. N., "Niger Delta Peoples and the Resource Control Conflict, 1960-1995: An Assessment of Conflict Handling Styles." In Perspectives on Peace and Conflict in Africa: Essays in Honour of General (Dr.) Abdulsalami A. Abubakar, edited by Isaac Olawale Albert, 170-181. Abuja: John Archers Publishers Ltd, 2005.

Olson, Williams M. J. "Preface: Small Wars Considered." The Annual of American Academy of Political and Social Science 541, no. 1 (1995), 8-19. DOI: 10.1177/0002716295541001001

Owonikoko, Saheed Babajide. "Kidnapping in Pre- and Post- Amnesty Niger Delta, Nigeria." International Journal of Peace and Conflict 3, no. 2 (2016), 63-77

"An Assessment of Government Engagement with Armed Groups in the Niger Delta Region." PhD diss., University of Ibadan, Nigeria, 2016.

"'Mutual Hurting Stalemate and Sense of a Way Out:' Interrogating the Niger Delta Presidential Amnesty Programme in Yar'Adua's Nigeria." In Governance, Security and Peacebuilding in the Niger Delta: Essays in Honour of Kingsley Burutu Otuaro, edited by Jarikre Mathias, Wilson U. Nsikanabasi and Oluwadare J. Abiodun, 118-139. Ibadan: Zenith BookHouse, 2018.

Rotberg, Robert I. "Deterring Mass Atrocity Crimes: The Cause of Our Era." In Mass Atrocity Crimes: Preventing Future Outrages, edited by Robert I. Rotberg, 1-24. Washington, DC: Brookings Institute Press, 2010.

Sesan, Kayode and Kingsley Kanayo. "President Buhari Approves Amnesty for Boko Haram." Breaking Times, August 6, 2015. Accessed April 19, 2017. https://www.thebreakingtimes. com/buhari-approves-amnesty-for-boko-haram/.

Smith, Michael. L.R. "Guerrillas in the Mist: Reassessing Strategy and Low Intensity Warfare." Review of International Studies 18, no. 1 (January 2003), 19-37.

DOI: 10.1017/S0260210503000020

Snow, Donald. Uncivil War: International Security and the New Internal Conflicts. Boulder: Lynne Rienner, 1996.

Stedman, Stephen John. “Spoiler Problem in Peace Process." International Security 22, no. 2 (1997), 5-53.

Turbiville, Jr, Graham H. "Preface: Future Trend in Low Intensity Conflict" Low Intensity Conflict and Law Enforcement 11, no. 2-3 (2002), 155-163. Accessed January 15, 2019. DOI: $10.1080 / 0966284042000279957$

Vanguard News. "Nigeria: FG, Not Us needs Amnesty- Boko Haram." Vanguard News, April 12, 2013. Accessed April 19, 2017. https://www.vanguardngr.com/2013/04/fg-not-us-needsamnesty-boko-haram/.

Woocher, Lawrence, "The Responsibility to Prevent: Towards a Strategy." In Routledge Handbook on the Responsibility to Protect, edited by Andy Knight and Frazer Egerton, 22-35. New York: Routledge, 2012. DOI: 10.4324/9780203117637.ch2 